\title{
PENINGKATAN HASIL BELAJAR TENTANG PENJAJAHAN BELANDA DAN JEPANG MELALUI MODEL MIND MAPPING PADA SISWA KELAS V SD
}

\author{
Tiara Yusuf \\ Universitas Negeri Malang \\ Email:yosefollo77@gmail.com
}

\begin{abstract}
Abstrak: Peningkatan hasil belajar tentang penjajahan Belanda dan Jepang melalui model Mind Mapping pada siswa kelas V SDN Karangrejo 04 Kabupaten Blitar. Penelitian ini membahas tentang penerapan model Mind Mapping dan peningkatan hasil belajar tentang penjajahan Belanda dan Jepang melalui model Mind Mapping pada siswa kelas V SDN Karangrejo 04 kabupaten Blitar. Aktivitas guru meningkat dari siklus I dengan ratarata persentase $76 \%$ menjadi $96 \%$ pada siklus II. Aktivitas siswa meningkat dari siklus I dengan rata-rata persentase $70 \%$ menjadi $81 \%$ pada siklus II. Peningkatan nilai akhir hasil belajar siswa pada siklus I dengan persentase ketuntasan rata-rata $70 \%$ meningkat pada siklus II menjadi $82 \%$.
\end{abstract}

Kata Kunci: peningkatan, hasil belajar, model mind mapping

Ilmu Pengetahuan Sosial (IPS) merupakan salah satu mata pelajaran yang ada di SD. Menurut Sumaatmaja (2007:1.9) "Ilmu Pengetahuan Sosial (IPS) merupakan mata pelajaran yang mempelajari kehidupan sosial yang kajiannya mengintegrasikan bidang ilmu-ilmu sosial dan humaniora". Melalui IPS siswa dapat memperoleh pengetahuan dan keterampilan dalam kehidupan sosialnya. Menurut BSNP (2006: 575) mata pelajaran IPS bertujuan agar siswa memiliki kemampuan mengenal konsep-konsep yang berkaitan dengan kehidupan masyarakat dan lingkungannya, serta memiliki kemampuan berkomunikasi, bekerjasama dan berkompetisi dalam masyarakat yang majemuk, di tingkat lokal, nasional, dan global.

Hasil belajar IPS siswa dapat diketahui setelah melakukan serangkaian proses belajar, mulai dari kegiatan pembelajaran serta tes atau evaluasi. Dimyati dan Mudjiono (2013:250) berpendapat bahwa "Ranah tujuan pendidikan berdasarkan hasil belajar siswa secara umum dapat diklasifikasikan menjadi tiga, yakni kognitif, afektif, dan psikomotor". Ranah ter- sebut dijadikan oleh guru sebagai aspek yang dinilai dalam pembelajaran. Siswa bertugas untuk mengikuti kegiatan pembelajaran sedangkan guru bertugas mengajar dan menilai pembelajaran dibidang kognitif berkenaan dengan hasil belajar intelektual, bidang afektif berkenaan dengan sikap, dan bidang psikomotor berkenaan dengan hasil belajar keterampilan dan kemampuan bertindak.

Hasil observasi yang dilakukan di Kelas V SDN Karangrejo 04 Kabupaten Blitar ditemukan bahwa dari 38 siswa terdapat 29 siswa yang mendapat nilai di bawah KKM atau jika dipersentasikan mencapai 76\%, sedangkan yang mendapat nilai di atas KKM hanya 9 siswa atau jika dipersentasikan hanya $24 \%$. Kebanyakan siswa tersebut mengalami kesulitan dalam pembelajaran Ilmu Pengetahuan Sosial (IPS), sehingga antusiasme dalam mengikuti pembelajaran IPS kurang. Hal tersebut tentunya berdampak pada hasil belajarnya yang kurang maksimal. Terdapat beberapa alasan yang menyebabkan hal tersebut di antaranya, (1) siswa merasa bosan 
sehingga kurang memperhatikan, (2) siswa kurang berpartisipasi dan aktif dalam proses pembelajaran karena terpusat pada guru, (3) siswa merasa kesulitan, karena pelajaran IPS cenderung menghafal materi, (4) siswa hanya diberi catatan yang biasa untuk mengingat materi pelajaran, (5) guru hanya memanfaatkan buku penunjang yang ada.

Rendahnya hasil belajar IPS di Kelas V SDN Karangrejo 04 Kabupaten Blitar merupakan alasan untuk merubah model pembelajaran IPS yang konvensional dengan model pembelajaran yang lebih inovatif dan menyenangkan yaitu dengan menggunakan model pembelajaran Mind Mapping. Menurut Buzan (2009: 4) Mind Mapping adalah cara mencatat yang kreatif, efektif, dan secara hafiah yang akan "memetakan" pikiran". Sedangkan menurut Silberman, (dalam Shoimin, 2014:105) Mind Mapping atau pemetaan pikiran merupakan cara kreatif bagi tiap pembelajar untuk menghasilkan gagasan, mencatat apa yang dipelajari, atau merencanakan tugas baru.

Menurut Kiranawati (2013: 32) Mind Mapping memiliki kelebihan antara lain (1) Dapat mengemukakan pendapat secara bebas, (2) Dapat bekerjasama dengan teman lainnya, (3) Catatan lebih padat dan jelas, (4) Catatan lebih terfokus ke materi, (5) Memudahkan penambahan informasi baru.

Penggunaan model pembelajaran Mind Mapping sebelumnya telah diteliti oleh Rahmawati (2015) dengan judul "Peningkatan Hasil Belajar IPS pada Siswa Kelas III Melalui Model Mind Mapping di SDN Kademangan 5 Kabupaten Blitar" dan terbukti bahwa penggunaan model pembelajaran Mind Mapping dapat meningkatkan hasil belajar siswa. Penelitian ini yang mendukung peneliti melaksanakan penelitian dengan judul: Peningkatan hasil belajar tentang penjajahan Belanda dan Jepang melalui model Mind Mapping pada siswa kelas V SDN Karangrejo 04 Kabupaten Blitar.

\section{METODE}

Pendekatan yang digunakan dalam penelitian adalah metode diskriptif kualitatif. Tek- nik analisa data kualitatif dilakukan dengan menelaah seluruh data, mereduksi data, menafsirkan data, dan memberikan pemaknaan hasil. Jenis penelitian yang akan digunakan Penelitian Tindakan Kelas (PTK). Alur pelaksanaan penelitian tindakan kelas diadaptasi dari Arikunto Arikunto dkk ( 2012: 16). Penelitian ini dilaksanakan selama 2 siklus, yang setiap siklus terdiri (1) perencanaan, (2) pelaksanaan, (3) pengamatan, dan (4) refleksi. Peneliti berperan sebagai instrumen sekaligus pengumpul data. Penelitian dilakukan secara kolaboratif, yaitu peneliti dibantu oleh guru kelas V SDN Karangrejo 04 Kabupaten Blitar yang bertindak sebagai pengamat (observer).

Subjek penelitian adalah guru dan siswa kelas V SDN Karangrejo 04 Kecamatan Garum Kabupaten Blitar, dengan jumlah siswa sebanyak 38 orang. Data pada penelitian ini adalah data proses dan hasil. Data proses diperoleh dari aktivitas siswa dan guru selama pembelajaran menggunakan model Mind Mapping. Sedangkan data hasil diperoleh dari tiga ranah, yaitu pengetahuan, sikap, dan keterampilan. Sumber data dalam penelitian ini berasal dari guru dan siswa SDN Karangrejo 04 Kabupaten Blitar. Siswa yang digunakan sebagai sumber data dalam penelitian adalah kelas V tahun ajaran 2015/2016 yang berjumlah 38 anak.

\section{HASIL}

Pada siklus I dapat direfleksikan bahwa dari segi guru sudah malaksanakan pembelajaran sesuai dengan RPP dengan menggunakan model Mind Mapping. Terjadi peningkatan aktivitas siswa dalam pembelajaran, aktivitas guru, dan hasil belajar dari pratindakan ke siklus I. Pada siklus I pertemuan I siswa telah nampak melakukan pembelajaran dengan menggunakan model Mind Mapping, siswa bersemangat dalam membuat Mind Mapping bersama dengan kelompoknya. Namun ketika guru sedang menerangkan dan membuat contoh Mind Mapping siswa masih banyak yang belum begitu paham, sehingga guru menerangkan kembali tentang menentukan 
kata kunci. Hal ini wajar dikarenakan siswa belum terlatih dan terbiasa menerapkannya. Banyak pula siswa yang menengok pekerjaan kelompok lainnya ketika sedang mengerjakan tugas. Keaktifan dalam menarik kesimpulan juga masih kurang. Pada siklus I pertemuan II sudah ada perbedaan yang terlihat, siswa sudah mulai terbiasa dan mengenal lebih dalam tentang cara membuat Mind Mapping dan cara menentukan kata kuncinya.

Model pembelajaran Mind Mapping telah terbukti mampu meningkatkan aktivitas dan hasil belajar siswa dari setiap pertemuan pembelajaran yang telah dilakukan. Persentase KBK yang diperoleh pada siklus I ini adalah sebesar $63 \%$ dengan sebanyak 24 siswa dari jumlah keseluruhan 38 siswa mendapat nilai diatas KKM. Karena persentase KBK belum mencapai $80 \%$ maka penelitian berlanjut pada siklus II.

Dari pengamatan selama pelaksanaan pembelajaran IPS dengan menggunakan model pembelajaran Mind Mapping pada siklus II menunjukkan adanya peningkatan dibandingkan siklus sebelumnya baik dari aktivitas guru, aktivitas siswa dan hasil belajar siswa. Siswa lebih mudah memahami dan diarahkan dalam kegiatan pembelajaran IPS dengan model Mind Mapping. Peningkatan tersebut antara lain, (1) Guru sudah memberi kesempatan kepada siswa untuk bertanya mengenai materi yang belum dipahami dan menjelaskan kembali, (2) Guru bersama dengan siswa menarik kesimpulan, (3) Guru sudah memberikan refleksi dan tindak lanjut, (4) Siswa sudah berani percaya diri dalam menceritakan hasil diskusinya dengan kelompok, (5) Hasil belajar siswa sudah memenuhi KKM yaitu 70 serta ketuntasan hasil belajar siswa sebesar $80 \%$ sudah tercapai,

Hasil analisis data dinyatakan bahwa aktivitas guru, aktivitas siswa, dan hasil belajar siswa melalui model Mind Mapping mengalami peningkatan. Berikut rekapitulasi aktivitas guru, aktivitas siswa, dan hasil belajar siswa.

Tabel 1 menginformasikan bahwa aktivitas guru pada siklus I pertemuan I sebesar $73 \%$, pertemuan II sebesar $80 \%$, sedangkan pada siklus II pertemuan I aktivitas guru sebesar $93 \%$, pertemuan II mencapai $100 \%$.

Tabel 2 menginformasikan bahwa aktivitas siswa pada siklus I pertemuan I sebesar $69 \%$, pertemuan II sebesar $72 \%$, sedangkan pada siklus II pertemuan I aktivitas siswa sebesar $75 \%$, pertemuan II mencapai $87 \%$.

Dari tabel 3 menginformasikan nilai rata-rata pratindakan sebesar 64 dengan persentase ketuntasan belajar klasikal hanya

Tabel 1 Rekapitulasi Aktivitas Guru Selama Siklus I dan II

\begin{tabular}{|c|c|c|c|c|c|c|}
\hline \multirow[b]{2}{*}{ Aspek } & \multirow[b]{2}{*}{$\begin{array}{l}\text { Hasil yang } \\
\text { Diperoleh }\end{array}$} & \multirow[b]{2}{*}{$\begin{array}{c}\text { Pra } \\
\text { Tindakan }\end{array}$} & \multicolumn{2}{|c|}{$\begin{array}{l}\text { Tindakan } \\
\text { Siklus I }\end{array}$} & \multicolumn{2}{|c|}{ Siklus II } \\
\hline & & & Pertemuan & $\begin{array}{l}\text { us I } \\
\text { Pertemuan }\end{array}$ & Pertemuan & $\begin{array}{l}\text { us II } \\
\text { Pertemuan }\end{array}$ \\
\hline $\begin{array}{c}\text { Aktivitas } \\
\text { Guru }\end{array}$ & $\begin{array}{c}\text { Persentase } \\
\text { KBK }\end{array}$ & - & $73 \%$ & $80 \%$ & $93 \%$ & $100 \%$ \\
\hline
\end{tabular}

\section{Tabel 2 Rekapitulasi Aktivitas Siswa Selama Siklus I dan II}

\begin{tabular}{|c|c|c|c|c|c|c|}
\hline \multirow[b]{2}{*}{ Aspek } & \multirow[b]{2}{*}{$\begin{array}{l}\text { Hasil yang } \\
\text { Diperoleh }\end{array}$} & \multirow[b]{2}{*}{$\begin{array}{c}\text { Pra } \\
\text { Tindakan }\end{array}$} & \multicolumn{2}{|c|}{ Siklus I } & \multicolumn{2}{|c|}{ Siklus II } \\
\hline & & & Pertemuan & Pertemuan & Pertemuan & Pertemuan \\
\hline $\begin{array}{l}\text { Aktivitas } \\
\text { Siswa }\end{array}$ & $\begin{array}{c}\text { Persentase } \\
\text { KBK }\end{array}$ & 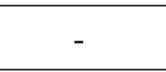 & $69 \%$ & $72 \%$ & $75 \%$ & $87 \%$ \\
\hline
\end{tabular}

Tabel 3 Rekapitulasi hasil belajar siklus I dan siklus II

\begin{tabular}{ccccccc}
\hline \multirow{2}{*}{ Keterlaksanaan } & \multirow{2}{*}{$\begin{array}{c}\text { Hasil yang } \\
\text { diperoleh }\end{array}$} & $\begin{array}{l}\text { Pra } \\
\text { Tindakan }\end{array}$ & $\begin{array}{c}\text { Pertemuan } \\
\text { I }\end{array}$ & $\begin{array}{c}\text { Sertemuan } \\
\text { I }\end{array}$ & $\begin{array}{c}\text { Sertemuan } \\
\text { I }\end{array}$ & $\begin{array}{c}\text { Pertemuan } \\
\text { I I }\end{array}$ \\
\hline \multirow{2}{*}{$\begin{array}{c}\text { Nilai Hasil } \\
\text { Belajar }\end{array}$} & $\begin{array}{c}\text { Rata-rata } \\
\text { kelas }\end{array}$ & 64 & 67 & 72,5 & 77 & 87 \\
\cline { 2 - 7 } & $\begin{array}{c}\text { Persentase } \\
\text { KBK }\end{array}$ & $24 \%$ & $50 \%$ & $63 \%$ & $76 \%$ & $89 \%$ \\
\hline
\end{tabular}


24\%, siklus I pertemuan 1 nilai rata-rata 67 dengan persentase ketuntasan belajar klasikal $50 \%$, pertemuan 2 nilai rata-rata 72,5 dengan persentase ketuntasan belajar klasikal menjadi $63 \%$, sedangkan pada siklus II pertemuan I nilai rata-rata 77 dengan ketuntasan belajar klasikal sebesar $76 \%$, pertemuan 2 nilai ratarata meningkat menjadi 87 dengan ketuntasan belajar klasikal $89 \%$.

\section{PEMBAHASAN}

Penerapan model Mind Mapping di Kelas V SDN Karangrejo 04 Kabupaten Blitar

Penerapan Model Mind Mapping di kelas V SDN Karangrejo 4 sudah dilakukan sesuai dengan delapan langkah yang sudah ditentukan, sehingga hasil belajar siswa mengalami peningkatkan. Dengan penerapan model pembelajaran Mind Mapping dapat meningkatkan kreatifitas, keaktifan, dan ingatan siswa lebih lama mengenai materi pembelajaran.

Silkus I pertemuan I aktivitas guru sejumlah 11 aspek yang sudah terpenuhi, dan terdapat 4 aspek yang belum terpenuhi. Pada pertemuan II sejumalah 12 aspek terpenuhi, dan terdapat 3 aspek yang belum terpenuhi, sehingga perlu adanya perbaikan pada siklus II. Sedangkan aktivitas guru pada siklus II pertemuan I sejumlah 14 aspek yang sudah terpenuhi dengan kualifikasi sangat baik dan terdapat 1 aspek yang belum terpenuhi yaitu memberikan tindak lanjut pada akhir pembelajaran. Siklus II pertemuan II sejumlah 15 aspek yang sudah terpenuhi dengan kualifikasi sangat baik. Penerapan sudah sesuai dengan langkah-langkah yang terdapat dalam RPP.

Aktifitas siswa siklus I pertemuan I, siswa kurang baik dalam indikator mendengarkan penyampaian tujuan, menyimak materi, pembentukan kelompok berpasangan, menyampaian hsil diskusi, menanyakan materi, dan membuat kesimpulan. Pertemuan II sudah mulai muncul peningkatan pada setiap indikator namun masih belum terpenuhi dan diperlukan perbaikan pada siklus II. Sedangkan pada siklus II pertemuan I sama dengan sebelumya masuk dalam kategori cukup dalam setiap aspek. Siklus II pertemuan II siswa sudah baik dalam kedelapan aspek yaitu mendengarkan penyampaian tujuan, menyimak materi, pembentukan kelompok berpasangan, memperhatikan, diskusi, menyampaikan hasil diskusi, menanyakan materi, dan membuat kesimpulan. Siswa sudah terbiasa dengan pembelajaran Mind Mapping, dan masuk dalam kategori baik. Aktivitas guru dan siswa mengalami peningkatan secara bertahap dari setiap pertemuan dalam siklus I dan siklus II, hal ini menujukkan pembelajaran dengan model Mind Mapping telah berhasil tercapai pada siklus II.

Melalui gambar atau kata kunci yang terdapat pada Mind Mapping siswa tahu ide pokok dari materi yang dibahas sehingga membuat siswa lebih mudah melihat gambaran yang mewakili semua pembahasan materi, mempermudah pemahaman, lebih kreatif, serta aktif dan mampu bekerjasama dalam kegiatan pembelajaran yang dilakukan.

Hal tersebut sesuai dengan kelebihan Mind Mapping, menurut Kiranawati (2013: 32) antara lain (1) Dapat mengemukakan pendapat secara bebas, (2) Dapat bekerjasama dengan teman lainnya, (3) Catatan lebih padat dan jelas, (4) Catatan lebih terfokus ke materi, (5) Memudahkan penambahan informasi baru. Sehingga melaui penerapan model Mind Mapping yang dilakukan, terjadi peningkatan dari aktivitas guru dan siswa.

\section{Hasil Belajar IPS melalui Model Mind Mapping pada Siswa Kelas V SDN Karangrejo 04 Kabupaten Blitar}

Siklus I pertemuan I aspek psikomotor (keterampilan) kerapian nilai tertinggi adalah 3 dengan jumlah 9 siswa (25\%). Sedangkan keterampilan dalam keterkaitan konsep nilai tertinggi adalah 3 dengan jumlah 11 siswa (29\%). Pada pertemuan II nilai tertinggi pada indikator kerapian yaitu 3 dengan jumlah 9 siswa (25\%). Pada keterampilan dalam keterkaitankonsepnilaitertinggiyaitu 3 dengan jumlah 13 siswa (34\%). Siklus II pertemuan I nilai tertinggi pada indikator kerapian yaitu 3 
dengan jumlah 15 siswa (39\%). Sedangkan indikator keterkaitan konsep nilai tertinggi adalah 3 dengan jumlah 14 siwa (37\%). Pada pertemuan II nilai tertinggi pada indikator kerapian adalah 3 dengan jumlah 6 siswa $(16 \%)$. Sedangkan pada indikator keterkaita konsep nilai tertinggi adalah 3 dengan jumlah 27 siswa (71).

Sikus I pertemuan I aspek afektif (sikap) nilai yang sering muncul pada indikator kerjasama yaitu 2 dengan jumlah 33 siswa $(87 \%)$. Pada kemampuan bertanya, nilai tertinggi adalah 3 dengan jumlah 5 siswa (13\%). Sedangkan kemampuan memperhatikan nilai tertinggi adalah 3 dengan jumlah 15 siswa $(39 \%)$. Pertemuan II, nilai yang sering muncul pada indikator kerjasama adalah 2 dengan jumlah 24 siswa (63\%). Pada kemampuan bertanya, nilai tertinggi adalah 3 dengan jumlah 13 siswa (34\%). Sedangkan kemampuan memperhatikan nilai tertinggi adalah 3 dengan jumlah 15 siswa (39\%).

Siklus II pertemuan I nilai yang sering muncul pada indikator kerjasama yaitu 2 dengan jumlah 24 siswa (63\%). Pada kemampuan bertanya nilai tertinggi adalah 3 dengan jumlah 17 siswa (45\%). Sedangkan kemampuan memperhatikan nilai tertinggi adalah 3 dengan jumlah 20 siswa (53\%). Pertemuan II, nilai yang sering muncul pada indikator kerjasama adalah 3 dengan jumlah 26 siswa (68\%). Pada kemampuan bertanya nilai tertingginya adalah 3 dengan jumlah 23 siswa (60\%). Sedangkan kemampuan memperhatikan nilai tertinggi adalah 3 dengan jumlah 27 siswa (71\%).

Siklus I pertemuan I dan II persentase klasikal aspek kognitif secara berturut-turut sebesar $45 \%$ dan $63 \%$ yang menunjukkan terjadi peningkatan pada siklus I namun belum mencapai ketuntasan. Pada siklus II pertemuan I dan II persentase klasikal secara berturut-turut sebesar $79 \%$ dan $84 \%$ yang menunjukkan terjadi peningkatan pada siklus II dan sudah mencapai ketuntasan.

Hasil penelitian menunjukkan bahwa model Mind Mapping dapat meningkatkan hasil belajar siswa pada materi Masa penjajahan Belanda dan Jepang. Hal tersebut nampak pada hasil belajar siklus I dan II. Pelaksanaan pratindakan diperoleh hasil ketuntasan belajar siswa sebanyak 9 siswa (24\%) tuntas, sedangkan 29 siswa (76\%) belum tuntas belajar. Hal tersebut menunjukkan pada pratindakan siswa belum tuntas dalam memahami materi dalam pembelajaran.

Pada siklus I pertemuan I diperoleh sebanyak 19 siswa (50\%) tuntas dan 19 siswa $(50 \%)$ belum tuntas. Pertemuan 2 diperoleh sebanyak 24 siswa (63\%) tuntas dan 14 siswa (37\%) belum tuntas. Dengan demikian terjadi peningkatan dari pertemuan I dan pertemuan II. Sedangkan pada siklus II dilakukan perbaikan dengan berdasarkan pada hasil refleksi siklus I diperoleh sebanyak 29 siswa (76\%) tuntas dan 9 siswa (24\%) belum tuntas. Pada pertemuan II diperoleh sebanyak 34 siswa (89\%) tuntas dan 4 siswa (11\%) belum tuntas. Dengan demikian terjadi peningkatan dari siklus I dan II, hasil belajar siswa dalam siklus II sudah terpenuhi. Hasil belajar tersebut terdiri dari tiga ranah, yaitu kognitif (pengetahuan), afektif (sikap), dan psikomotor (keterampilan). Hal tersebut sesuai dengan pendapat Dimyati dan Mudjiono (2013:250) berpendapat bahwa "Ranah tujuan pendidikan berdasarkan hasil belajar siswa secara umum dapat diklasifikasikan menjadi tiga, yakni kognitif, afektif, dan psikomotor".

Sehingga dari hasil penelitian yang telah dilakukan menujukkan bahwa melalui model Mind Mapping dapat meningkatkan hasil belajar IPS pada siswa kelas IV SDN Karangrejo 04 Kabupaten Blitar..

\section{PENUTUP}

\section{Kesimpulan}

Penerapan model Mind Mapping pada pembelajaran IPS di kelas V SDN Karangrejo 4 Kabupaten Blitar telah dilaksanakan dengan baik, melalui langkah-langkah yaitu (1) guru menyampaikan tujuan pembelajaran yang akan dicapai siswa, (2) guru menyajikan materi, (3) guru membentuk siswa menjadi kelompok 
berpasangan, (4) Guru menerangkan dan membuat contoh singkat Mind Mapping, (5) guru memberi tugas siswa untuk membuat Mind Mapping, (6) guru menunjuk perwakilan kelompok maju ke depan kelas untuk mnyampaikan hasil diskusinya, (7) guru memberi kesempatan siswa untuk bertanya mengenai materi yang belum dipahami dan menjelaskan kembali materi tersebut, (8) guru bersama siswa menarik kesimpulan dari pembelajaran yang telah dilakukan. Siswa nampak bersemangat, aktif dan mampu bekerjasama dengan kelompok. Kreatifitas dan ide-ide yang dimiliki disalurkan dalam pembuatan Mind Mapping, serta sudah berani dalam mengungkapkan pendapat maupun bertanya mengenai materi yang belum dipahami.

Hasil belajar siswa melalui model Mind Mapping dalam pembelajaran IPS meningkat dari pratindakan ke siklus I dan Siklus II. Peningkatan hasil belajar IPS pada siswa kelas V di SDN Karangrejo 4 Kabupaten Blitar meliputi nilai sikap, pengetahuan, keterampilan, dan nilai akhir menggunakan model Mind Mapping ditunjukkan dengan rata-rata persentase ketuntasan klasikal pada pratindakan sebesar $24 \%$, siklus I pertemuan I (50\%), pertemuan II (63\%), sedangkan pada siklus II pertemuan I $(76 \%)$, pertemuan II $(89 \%)$.

\section{Saran}

Saran berikut dapat dijadikan sebagai referensi yang dapat diterapkan dalam upaya meningkatkan pembelajaran di Sekolah Dasar khususnya pada mata pelajaran IPS.

Guru hendaknya menggunakan model pembelajaran Mind Mapping karena model pembelajaran ini dapat meningkatkan aktivitas siswa dalam pembelajaran IPS. Guru hendaknya menggunakan model pembelajaran Mind Mapping karena model pembelajaran ini dapat meningkatkan hasil belajar siswa pada mata pelajaran IPS.

Peneliti lanjutan hendaknya menerapkan model pembelajaran Mind Mapping agar siswa lebih aktif dan terlibat langsung dalam pembelajaran. Peneliti lanjutan hendaknya menyesuaikan model pembelajaran Mind Mapping sesuai dengan perkembangan jaman sehingga siswa lebih mudah untuk mendapatkan manfaat dan merasakan keterkaitan langsung model pembelajaran ini dengan kehidupan sehari-hari.

\section{DAFTAR RUJUKAN}

Arikunto, Suharsimi dkk. 2012.Penelitian Tindakan Kelas. Jakarta: Bumi Aksara.

Asmorowati, Dewinta. 2013.Peningkatan Keterampilan Menulis Karangan Narasi Melalui Mind Mapping Berbantuan Gambar pada Siswa Kelas IV SDN Nguliyan 01 Semarang. Semarang: Universitas Negeri Malang

BSNP. 2006. Standar Isi. Jakarta: Badan Standar Nasional Pendidikan

Buzan, Tony. 2009. Buku Pintar Mind Map. Jakarta: Gramedia Pustaka Utama.

Dimyati dan Mujiono. 2013. Belajar dan Pembelajaran Cetakan Kelima. Jakarta: Rineka Cipta.

Shoimin, Aris. 2014. 68 Model Pembelajaran Inovatif dalam Kurikulum 2013. Yogyakarta: Ar-Ruzz Media

Sumaatmadja, Nursid. 2007. Konsep Dasar IPS. Jakarta : Universitas Terbuka 